\title{
Database Lock
}

National Cancer Institute

\section{Source}

National Cancer Institute. Database Lock. NCI Thesaurus. Code C142503.

A database status, that occurs after the final database freeze event, in which the database disallows any additional changes. Database unlocking may occur but requires certain permissions. 